\author{
Christian Erbacher, Anne dos Santos Reis \& Julia Jung \\ christian.erbacher@uni-siegen.de
}

\title{
“Ludwig Wittgenstein" - A BBC radio talk by Elizabeth Anscombe in May 1953
}

\author{
Edited by Christian Erbacher (University of Siegen), Julia \\ Jung (University of Siegen) and Anne dos Santos Reis \\ (University of Siegen)
}

\section{Abstract}

Presented here is the transcript of a BBC radio broadcast by Elizabeth Anscombe that was recorded in May 1953 - the month when Wittgenstein's Philosophical Investigations appeared in England for the first time. In her radio talk, Anscombe provides some biographical and philosophical background for reading the Philosophical Investigations. She addresses the importance of the Tractatus and of the literary qualities of Wittgenstein's writing. Anscombe warns that it would be fruitless to adopt slogans from Wittgenstein without insight. She also calls it a misunderstanding to think that Wittgenstein had championed something like the Ordinary Language Philosophy as it was practised at the time of the recording.

\section{Introduction}

In October 1944, after a prolonged leave of absence during the Second World War, Wittgenstein resumed lecturing at Cambridge University. Among the attendees of his lectures that dealt with the philosophy of psychology was Elizabeth Anscombe, who had come to Cambridge with a studentship from Newnham College (Wittgenstein 2003: 355-356). She had already shown her 
extraordinary capacity for philosophical questions while studying at St. Hugh's College in Oxford, but it was only in Wittgenstein's classes that she experienced an extraction of the "central nerve" of her philosophical perplexities (Anscombe 1981: xiii-xiv). In turn, Wittgenstein soon recognized Anscombe as being one of the ten best students he ever had (cf. Wittgenstein 2012: No. 324). Before another year had passed, Anscombe started to learn German:

I told Wittgenstein, and he said 'Oh, I am very glad, for if you learn German, then I can give you my book to read'. This had been my hope, and it spurred me on. We read the introduction to Frege's Grundlagen together. He professed amazed admiration at my laying hold of the construction of the sentences. He said, what no doubt was true, that it must have been the fruit of a training in Latin. But I was struck by the incongruousness of his admiring the exercise of so elementary a skill, which I thought a very slight display of intelligence, when one could get into fearful trouble in his lectures for not grasping something which I was sure it needed great powers and hard thought to grasp. We eventually read the early part of the Investigations; I remember he reacted with real pleasure when I told him that I had read to $\$ 35$ and had found it intoxicating; which was the case. As we read it we discussed translating it-he would explain the import of words, and I would suggest an English rendering, about which he would be very enthusiastic. (Anscombe 1946, transcription by L. Gormally, quoted from Erbacher 2016: 29)

Wittgenstein had tried to find a translator for his work before the war. But none of the candidates had delivered a satisfying result. The joyful experience of toying with the translation together with Anscombe may have incited him, in their subsequent meetings, to ask her to do it. By early 1950 at the latest, when Wittgenstein had been diagnosed with cancer upon his return from the USA, Anscombe had committed herself to translating Wittgenstein's book. To prepare for the task, she spent several months in Vienna studying Viennese German (Wittgenstein 1988: xiii). Wittgenstein, who had arranged for her to stay at the house of his good friend Ludwig Hänsel, was present for part of the time (note from L. Gormally, see Erbacher 2016: 29). By April 1950, both Wittgenstein and Anscombe had returned from Vienna, and Wittgenstein moved into Anscombe's slim Oxford townhouse. Here they resumed translating the then-current version of the 
Philosophical Investigations. According to Anscombe's husband Peter Geach, the translation of all remarks was finished while Wittgenstein was still alive (Wittgenstein 1988: xiii). What is more, Jenny Teichman, a friend of Anscombe's family, noted that the translation was carried out under Wittgenstein's guidance (Teichman 2001: 2). Indeed, given Wittgenstein's great interest in earlier attempts to translate his work, it is hard to imagine that he would not be involved in some way in Anscombe's work. What is most likely is that they cooperated in a way that would allow Anscombe to sharpen her apprehension of Wittgenstein's writing and how to render it into English. She certainly could build on these experiences after Wittgenstein's death, when she translated the remarks she and Rhees included as "Part II" of the Philosophical Investigations, and when she prepared the whole translation for print. In any case, Anscombe did not stop searching for mistakes and ways to improve the text until the book went to press in 1953, and she continued even after that, as she wrote to von Wright:

I hope you like the book.- I've been reading out translation mistakes for the American edition, but the axe has fallen now and they will accept no new corrections; though I still have one or two to make. Ryle has agreed to publish a list of my corrections in the July Mind. (Letter Anscombe to von Wright, 17 May 1953)

The result of Anscombe's tireless efforts is well known: a translation that Anthony Kenny eloquently described:

The Anscombe translation is fluent and readable and has been universally accepted as if it contained the ipsissima verba of Wittgenstein: I can think of no other English translation of a philosopher - not Jowett's Plato, nor Kemp Smith's Kant - that has achieved such canonical status in the world. (Kenny 2005: 342)

In the moment of adding the last strokes to this monumental achievement of translating the Philosophical Investigations, Anscombe did a recording for the BBC Third Programme. In two continuous broadcasts, she gave a talk on Wittgenstein (recorded probably on 2 May 1953, broadcasted on 9 July 1953, 8.05 pm) and read out the passage on "reading" from her translation of the Philosophical Investigations (recorded on 2 May 1953, broadcasted on 11 July 1953, $9.35 \mathrm{pm})$. Presented below is a transcript of the manuscript used 
for the first recording, that is, Anscombe's talk on Wittgenstein in connection with the publication of the Philosophical Investigations. The document testifies to Anscombe's awareness of Wittgenstein and his work at a time when her memories of him were still fresh and she was fully immersed in the translation project. This makes the BBC radio talk a valuable source for learning about Anscombe's understanding of Wittgenstein's philosophy and about the standards according to which she measured her translation. She says, for instance, that translating Wittgenstein is particularly difficult, because his style is at the same time literary and colloquial and that this combination does not work in English. This apprehension fits well with what she wrote to Brian McGuinness, referring to Frank Ramsey's translation of the Tractatus:

Wittgenstein's German is always very expressive; sometimes very plain, even colloquial, and straight, always terse, sometimes splendid and rather poetic; it has great rhythm. Now Ogden has something of this in him. Only in him it splits up into two things, one meretricious and the other not. It's meretricious when there is an air of profundity through obscurity and almost pseudo Biblical or pseudo poetic language. But when his methods of translation don't lead to this, and don't contain errors, they sometimes have beauty and force. They are never heavy or academic. (Letter from Anscombe to McGuinness, undated)

Where Ramsey succeeded in translating Wittgenstein, Anscombe admired his "free but excellent renderings" (Anscombe 1959: 17), and this may be a heuristic she adhered to in translating the Philosophical Investigations.

The BBC radio broadcast was an occasion to announce Wittgenstein's work to the broader philosophically interested public. Hence, it is most interesting to see how Anscombe described it in an accessible language and how she placed the Philosophical Investigations in the philosophical landscape of the time. Being broadcast in the heyday of the "Ordinary Language Philosophy" at Oxford, Anscombe was keen to distinguish Wittgenstein's philosophy from this philosophical movement. She thus argued against a tendency in the then upcoming historiography of the analytical tradition that presented Wittgenstein primarily as Bertrand Russell's student who had 
elaborated his teacher's logical atomism and then paved the way for the logical positivism of the Vienna Circle (cf. Conant 2015). According to this view, Ordinary Language Philosophy was said to bring to full fruition what Wittgenstein had only hinted at (cf. Urmson 1956). By contrast, Anscombe insisted that this would be a gross misunderstanding of Wittgenstein's work; it had to be read against another background: first, the Tractatus would remain incomprehensible if the influence of Gottlob Frege's work was neglected; and second, the Philosophical Investigations had to be read against the background of this Frege-oriented understanding of the Tractatus. In her talk for the BBC, Anscombe took the opportunity to champion both this line of philosophical heredity (FregeTractatus-Philosophical Investigations) as well as the unique freshness of method and style in the writings that Wittgenstein had left behind.

\section{References}

Anscombe, G. E. M., 1953. Letter to von Wright, 17 May 1953. National Library of Finland, NLF COLL. 714.11-12; quoted with permission from Mrs M. C. Gormally (Dr Mary Geach).

Anscombe, G. E. M., n. d. Letter to McGuinness. McGuinness's private archives, now kept at the Brenner Archives at the University of Innsbruck; quoted with permission from Mrs M. C. Gormally (Dr Mary Geach) and Brian McGuinness.

Anscombe, G. E. M., 1959. An Introduction to Wittgenstein's Tractatus. London: Hutchinson.

Anscombe, G. E. M., 1981. Metaphysics and the Philosophy of Mind - Collected Philosophical Papers of G. E. M. Anscombe, Vol. II. Oxford: Blackwell.

Conant, J., 2015. "The Emergence of the Concept of the Analytic Tradition as a Form of Philosophical Self-Consciousness". In: J. A. Bell, A. Cutrofello, and P. M. Livingston, eds. 2015. Beyond the AnalyticContinental Divide. Pluralist Philosophy in the Twenty-First Century. New York: Routledge, pp. 17-58.

Erbacher, C., 2016. "Wittgenstein and His Literary Executors: Rush Rhees, Georg Henrik von Wright and Elizabeth Anscombe as Students, Colleagues and Friends of Ludwig Wittgenstein." Journal for the History of Analytical Pbilosophy 4 (3), pp. 1-39.

Kenny, A., 2005. "A Brief History of Wittgenstein Editing”. In: A. Pichler and S. Säätelä, eds. 2005. Wittgenstein: The Philosopher and His Works. Wittgenstein Archives at the University of Bergen (WAB), pp. 341355. 
Teichman, J., 2001. “(Gertrude) Elizabeth Margaret Anscombe (19192001)". In: Oxford Dictionary of National Biography < https://doi.org/10.1093/ref:odnb/75032> (accessed 20 May 2019).

Urmson, J. O., 1956. Philosophical Analysis: Its Development between the Two World Wars. Oxford: Oxford University Press.

Wittgenstein, L., 1988. Wittgenstein's Lectures on Philosophical Psychology 19461947, ed. P. T. Geach. Chicago: University of Chicago Press.

Wittgenstein, L., 2003. Ludwig Wittgenstein: Public and Private Occasions, eds. J. C. Klagge and A. Nordmann. Lanham, MD: Rowman \& Littlefield. Wittgenstein, L., 2012. Wittgenstein in Cambridge: Letters and Documents 1911_ 1951, ed. B. F. McGuinness. Malden, MA: Wiley-Blackwell.

\section{Editorial Note}

The manuscript kept at the BBC Archives is written in Anscombe's own handwriting, with the exception of technical instructions on the front page that are written with a typewriter, and a note for the radio programme inserted in different handwriting on page 2. Apart from the title that stems from the typewritten front page and that is transcribed below in capital letters, only Anscombe's handwritten talk is represented. The manuscript contains deletions, corrections and insertions so that it seems that Anscombe revised wording in the process of drafting. Though these revisions are sometimes illuminating, the edition does not represent them for the sake of readability. Thus, what is presented below is a normalized transcript, in which Anscombe's deletions, corrections and insertions have been omitted. The result is a fair copy, most likely resembling the text that Anscombe read for the broadcast. Line breaks and page breaks of the manuscript have not been preserved. Occasional additions or suppositions by the editors are placed in rectangular brackets.

\section{Acknowledgements}

Anscombe's manuscript has been reproduced and edited with permission from Mrs M. C. Gormally (Dr Mary Geach) and the BBC. The document was found and analyzed during a Research Fellowship at the Research Centre for Analytic German Idealism at the University of Leipzig (FAGI). The editorial work has been funded by the Collaborative Research Centre "Media of Cooperation" at the University of Siegen (SFB 1187). For most helpful support in deciphering Anscombe's handwriting I am very grateful to Luke Gormally. 


\section{LUDWIG WITTGENSTEIN}

\section{TALK BY G. E. M. ANSCOMBE}

Wittgenstein came to Cambridge, I think in the year 1911, at the age of twenty two, in order to study under Bertrand Russell. He had been to school in Austria and had studied engineering for some years in Manchester. After a few months it was arranged, by the help of Russell and of the logician Johnson, that he should not have to read the Tripos but should be accepted as a $\mathrm{PhD}$ student straight away. As he had no degree and no previous study of philosophy to recommend him, this is some indication of the impression he made on his teachers.

For the next 7 years he was engaged in writing the 'LogischPhilosophische Abhandlung', most generally known under the title given to its English translation: Tractatus Logico-Philosophicus. The book itself is short: this is because it is extremely compressed. A very great mass of writing lay behind it. (This Wittgenstein had burned in 1950 in view of his approaching death; it comprised several boxes full of MS volumes.) Someone who admired his 'Philosophical Investigations' once asked him why he called it not good. He turned the pages over with an expression of distaste, and then said "It limps." And then "If this were philosophy, you could learn it by heart!" This singular ideal he did achieve in his first book.

Philosophical influences on him were few but powerful. As a boy of 16 he read Schopenhauer's 'World as idea and will', and thought it tremendous: as far as the 'world as idea' was concerned, he thought what Schopenhauer said true, only needing a few adjustments. Later he characterised S. as a thinker capable [of] a certain limited depth and no more. The great influence on him was Frege, for whom he always had the most 
intense admiration both as a writer and as a thinker, and to whom he presents certain marked similarities. To Bertrand Russell he owed a very great deal, mostly to Russell in discussion in the period 1911-14. He often spoke of how wonderful Russell was to discuss with in that period. The best introduction I know of to Wittgenstein's Tractatus [-] if you sift out Russell's phenomenalism [-] is to be found in Russell's Lectures on Logical Atomism, delivered in 1918, in which Russell says: "They are very largely concerned with explaining certain ideas which I learned from my friend and former pupil Ludwig Wittgenstein." This was of course written before the Tractatus appeared: the lectures are a reflection of the discussions which they had together before the first world war.

Otherwise in philosophy, one can only speak of likings not of influences. Wittgenstein had a liking for Plato, a great love of St. Augustine (in the Confessions only) and a fondness for William James (in the Principles of Psychology); also a certain limited liking for Aquinas: that is limited to some of the questions that Aquinas asked. I should add to this list Lichtenberg, of whom Goethe said "Where Lichtenberg makes a joke, there you will find a problem." There are passages in Lichtenberg that are extraordinarily like Wittgenstein: "Yes, I might have written it myself," he said once on being shown an unfamiliar paragraph of Lichtenberg:

The thing that makes the study of any profound philosophy so very difficult is that in everyday life we take lots of things to be so natural and easy, that we think things just couldn't be otherwise. And yet we ought to know that one needs to realise the enormous importance of such apparent trifles before one can explain the difficulty that is spoken of really is one. When I say: This stone is hard and so first attach the concept stone which belongs to a plurality of things, to this individual, and then speak of hardness [,] and then combine the being 
hard with the stone - this is such a miraculous operation that we may ask whether so much goes into the preparation of some books. "But aren't these subtleties? does one have to know this?" - As far as the first question goes, they are not subtleties, for it is just in these simple cases that we must get to understand the operations of the mind. If we try to begin with complex ones, all our labour is lost. Finding these easy things difficult betrays no small advance in philosophy. But as far as the other question goes, I answer: No, one doesn't have to know it, but one doesn't have to be a philosopher either.

There is a set of German writers - I don't think I can speak of a tradition whose style has a special daylight character: tough, lucid, crisp, lively and serious: Lessing, Lichtenberg, Frege, all display to a less or greater degree the character I have in mind; and Wittgenstein preeminently.

Of all other philosophers, besides the ones I have mentioned, Wittgenstein was on the whole ignorant. He would sometimes read a page, and find himself unable to go on. If he mentioned any philosopher, it was to quote and comment on some quite concrete remark; he never made general remarks on philosophers' views. (This has had an odd effect on some of those who directly or indirectly, have been influenced by him. It is fairly common now to read criticisms at large of celebrated philosophers backed by a rather slight consideration of their writing.)

The Tractatus is of the greatest possible importance for understanding the 'Philosophical Investigations'. W. came to realise this and wanted the two books bound up together, which will, I hope, be done in a purely German edition. It is important because Wittgenstein clearly remained in love with the thoughts of the Tractatus, though he attacks and most powerfully undermines them. The Tractatus haunts the Investigations. 
It is quite commonly said that Wittgenstein taught, not a doctrine, but a method of doing philosophy. This is unluckily in an important sense not true. If someone teaches a method, it ought to be possible for someone else both to learn and to teach it: it ought to be quite clear what the procedure is, what moves you make at what points, and so on. Now it is possible perhaps to list a number of tricks which Wittgenstein used and, therefore, taught. E.g., that of asking "As opposed to what?" or "and what would it be like if it were not so?" when a proposition is advanced. Or that of asking "What is the picture that is being used here?". Or that of taking a solution in a peculiarly literal, empirical sense. Or that of inventing different cases which shew quite clearly that the implication of a term or the meaning of a statement is not determined in advance in some way in which one thought it was. Or that of asking 'To whom is this said, and in what circumstances?' or 'What kind of proposition is this?'. Or that of assuming a criterion of identity of a kind suggested by a philosophic thesis and deducing absurd consequences. Or that of asking what would shew that a word had a certain sense if you had to learn the language it belonged to without interpreters. I could go on. But none of these moves, nor all of them taken together, guarantee that anybody will find a solution to any problem at all. There is no method taught by which you know when such and such a move will be fruitful, carry you deeper, cause you really to touch the nerve of the problem under consideration. These tricks can be played with complete superficiality. Nothing takes the place of having ideas, of being capable of observation and insight; and Wittgenstein did not I think teach a method of attaining these. When he makes one of these moves it has great point; but he does not teach you when it will have point to make a given move.

He had a great and a bad influence on current philosophy. He knew this: "But," he said, "I don't think its my fault." It is possible to point to certain definite phenomena as examples of his bad influence. A certain 
amount of current philosophical discussion concerns itself with linguistic usage. This is a direct result of Wittgenstein's teaching that in a great many cases, in which we speak of 'meaning', though not in all, it can be defined thus: the meaning of a word is its use in the language. But use is not usage; he did not wish to base anything on idiom. "I distinguish," he wrote "between the essential and the inessential features of an expression. The essential features are the ones that would make us translate some otherwise unfamiliar form of expression into this, our customary form." What is or is not correct English usage is of no conceivable philosophic interest; nor does it matter if I choose to use words in an extraordinary manner, so long as it [is] clear what I am saying. So far, I think you can say that 'it's not his fault'. On the other hand the objection "but the word is not used like that"[;] "but we don't say that"; "but that is not how this statement is used", which has acquired such dogmatic force in philosophical discussion, is more directly his responsibility. It ought, however, never to be used unless it is clearly shewn how, for the particular problem in hand, some particular feature of a use is essential to a meaning. Otherwise it is the expression of a philosophical dogma of which some are addicts, while others cannot see the point at all. (And they are right.) Wittgenstein was not an addict of this dogma: but it may not always be clear that he was not. He is always saying 'look at the use!' But it is in fact a difficult thing to do; and it is very easy to think that one is doing it by attending to unimportant features: a procedure which he once compared to describing a naval lieutenant in terms of the stripes on [his uniform.]

Here I can mention the misinterpretation of Wittgenstein's work which I can most easily foresee, and which I believe will be the dominant one. It will be thus: Wittgenstein formulates (with great subtlety) a theory of meaning as use: and what else he says is a deduction from, or a working out of, this theory. Those who are not caught up by the theory, but who hear of 
it, will probably notice it as a puzzling thing that work of which this is the sum should have so excited and fascinated people. - It will be a complete misunderstanding. In what Wittgenstein has to say about use he manufactures one tool which he employs in philosophical investigation. No part of his work presupposes another as a theoretical foundation: he does not treat his problems from the point of view of a system which he is engaged in constructing. This fact may be obscured by the fact that some parts of the book do presuppose others in the sense that you will perhaps not understand the methods of argument employed without having read certain passages.

In the style used by people talking [and] writing philosophy his influence has been very marked and often very disagreeable. He was unacademic both in manner and in matter; some people found this novel and stimulating and tried in one way or another to imitate it, sometimes with embarrassing results: a would be humanism of style \& examples.

Further, it is true - though not at all informative - to say that Wittgenstein's way of dealing with philosophical problems ends, if it is successful, in their dissolution rather than in the presentation of a theory. When you consider this; and consider also how it was carried out: in an unsystematic way, accompanied by wit and imagination; always making the impression of very fresh and very hard thinking; supported by striking examples and analogies; full of an obvious passion for the subject, of a kind not often to be met with - when you consider all this, it becomes easy to understand how it often went to the heads of his listeners. Then they would try to deal with problems in the same way, to achieve the same effect: and as the effect was the dissolution of the problems, they would make that their aim. Thus it has come about that a great deal of the philosophy written at the present day consists in a debunking and shelving of problems without 
serious investigation: the lengthiness of what is written or said consisting of tedious linguistic description or the like.

One of the best known writings which shew his influence is Professor Ryle's Concept of Mind. One of Professor Ryle's purposes in this book is to depreciate the role of formulated thought in the life of human beings. The kind of examples of intelligence that must suit his purpose are such things as the tumbling of clowns, playing football, tying your bootlaces, which are certainly intelligent and purposive, but the execution of which perhaps does not require the presence of what are ordinarily called mental acts. Throughout the book Professor Ryle is at ease when he is describing the actions which are the expression of mental acts, and evasive when he is in danger of pinning himself down to considering a mental act divorced from action; he tends to content himself with denying that we need to have any hidden process described to us, and with affirming that we all know quite well from childhood in what situations we describe people as, e.g. imagining. The contrast with Wittgenstein [is] strong; for Wittgenstein is not at all interested in things like tying shoelaces or playing football, but entirely absorbed by such questions as what it is to grasp a rule, to mean or understand an order, to recognize the same, to take a word in a sense, to suddenly see how to continue a series, to have been going to say something, to mean a man by his name, and so on. Professor Ryle, writing on volition, hardly does more than ridicule the idea of a "mental" or as he also calls it a "ghostly" "thrust". He does not confront himself with the problem; which Wittgenstein states thus: "When I raise my arm, my arm goes up. What is left when I subtract the fact that my arm goes up from the fact that I raise my arm?"

"I spend more time than you perhaps could ever understand, thinking about questions of style," Wittgenstein once said to someone. The state of the MSS and TSS that he left behind him are a witness to this. He wrote an 
enormous amount; he threw away a good deal, and what is left is a formidable quantity of MSS written from 1929 onwards. He would often write first in small notebooks, then transfer siftings from these to larger ones, then further-polished-siftings to still larger ones. Then he would dictate to a typist. Then [he] would cut up the typescript and throw a lot away, and try different arrangements of the rest: for he always wrote in the form of isolated paragraphs capable of rearrangement. A great part of the material of the Philosophical Investigations exists in two other quite different arrangements, each brought to a final form and ready for the printer, and each elaborately cross referenced; for he hoped at one time to supply his 'Remarks' as he called them, with cross references to every other one with which he saw a fruitful connexion. His MSS. sometimes contain remarks written over and over again in various forms. They always contain a huge number of variant readings, with variant punctuations; and if you read carefully through each possibility, you notice how sharply aware Wittgenstein was of small rhetorical differences.

The final product of all this work has very remarkable literary qualities; once it is published, I think there will be no more wonderment why Wittgenstein - who spoke English well - wrote in German. It was horribly difficult to translate. I doubt whether much of a reflection of its style would be possible in English at all; at any rate it was not possible for me to achieve it. In general, German has possibilities of a homeliness - the very epithet sounds horrid in connexion with English - that is not in the [slightest] in conflict with the highest literary style. For an example, you only need to look at Gretchen's lines in Faust when she comes in after Faust and the Devil have been in her room. Wittgenstein's German is at once highly literary and highly colloquial. Good English, in modern times, goes in good clothes; to introduce colloquialism, or slang, is deliberately to adopt a low style. Any English style that I can imagine would be a misrepresentation of this 
German. All I could do, therefore, was to produce as careful a crib as possible. I bent over backwards to write in a spare and compressed English, since the German is spare and compressed; and in part I the translation turned out several lines a page shorter than the original. (This was right, because English is a shorter language than German.) But in part II I found, when it was set up, that the German was seldom longer and was sometimes shorter. This is one small index of the new degree of compactness to which Wittgenstein rose in his last period; for compression, together with rich and sharp expressiveness; for wealth of incontestable observations and hard investigation; this transcends everything he ever wrote.

The constant characteristics of Wittgenstein's writing are close reasoning and strong imagination. But the book has also the character of great variety of tone: this is a rare character, and particularly rare in philosophical writing. (The only other examples I can think of are some of Plato's dialogues). You get long passages of very sober, straightforward enquiry and argument; then a burst of breathless dialogue (always, of course, between himself and himself); sudden turn of humour, passages full of passionate feeling; pronouncements reached after perplexed enquiry, which have the air of being written with that feeling: And that settles everything; pieces of delicate, accurate characterisation of some particular temptation; remarks that are like a grasp or cry of realisation. And you get certain themes, certain moods recurring and recurring with different variations. I have long been tempted to compare this book with a musical composition; but hesitated to do so, until I found it elicited this reaction independently from someone who read it de novo.

One of the things which will interest me very much will be German reactions to the book as a literary achievement. 


\section{Biographical Note}

Christian Erbacher (b. 1979) received his diploma in psychology from the University of Regensburg (Germany) in 2006 and his $\mathrm{PhD}$ in philosophy from the University of Bergen (Norway) in 2010. Between 2010 and 2015 he has conducted the research project "Shaping the Domain of Knowledge by Editorial Processing: the Case of Wittgenstein's Work". He is continuing his work on the history of editing Wittgenstein's writings as part of the Collaborative Research Center "Media of Cooperation" at the University of Siegen.

Julia Jung (b. 1992) studies Literature, Culture and Media at the University of Siegen. Since 2016 she is working at the Collaborative Research Center "Media of Cooperation" at the University of Siegen.

Anne dos Santos Reis (b. 1992) studies philosophy and linguistics at the University of Siegen. Since 2016 she is working at the Collaborative Research Center "Media of Cooperation" at the University of Siegen. 